\title{
Recent Advancements in Antipsoriatic Therapy: An Update
}

\author{
Shaik SHAFIULLA*(D), Suneela DHANESHWAR ${ }^{* *}$, o[D
}

Recent Advancements in Antipsoriatic Therapy: An Update

\section{SUMMARY}

Psoriasis is a chronic inflammatory, a multisystem autoimmune disease with extreme pathological features and unsatisfied pharmacotherapeutic needs. Primarily psoriasis is associated with epidermal cells, keratinocyte hyperproliferation, inflammation, dermal capillary dilation, and proangiogenic mechanisms. Compared with other chronic diseases, patients with psoriasis have severe psychological stress and undergo reduced physical activeness, cognitive dysfunctions, and low-quality life. Pathophysiology is complex with the involvement of various mediators like interleukin(IL)-17, IL-23, tumor necrosis factor-alpha (TNF- $\alpha$ ), interferongamma (IFN- $\gamma)$, and vascular endothelial growth factor (VEGF) that play a significant role in escalation and localizing the inflammation caused in psoriasis. However, acquiring uninterrupted knowledge of psoriasis pathophysiology allows us to identify the novel therapeutic targets that could be explored to overcome personalized psoriasis treatment challenges. Conventional therapy includes corticosteroids, vitamin-D, methotrexate, and cyclosporine, but with low efficacy and severe side effects and sometimes causing disease comorbidities. New biologics approved by FDA during 2016-2019, such as IL-23 blockers risankizumab-rza, guselkumab, and tildrakizumab-asmn, certolizumab pegol targeting TNF- $\alpha$, IL-17 blockers brodalumab and ixekizumab have revolutionized the treatment of moderate to severe psoriasis due to targeted approach but are reported to possess many side effects leading to low patient compliance. Biosimilars of adalimumab, etanercept, and infliximab, designed by reverse engineering of biologics, are also becoming popular due to their cost-effectiveness. Drug repurposing focuses mainly on defining new medical uses for old drugs. The main focus of drug repurposing is how the drug molecule interacts with various targets and executes its pharmacological action, revealing the new possibilities of designing effective therapeutic agents with low toxicity.

Key Words: Psoriasis; Drug repurposing, Angiogenesis, Vascular endothelial growth factor, Keratinocyte proliferation, $T N F-\alpha, I F N-\gamma$, Th-17/Th-23 pathway

\section{Antipsoriatik Tedavide Son Gelişmeler: Bir Güncelleme}

$\ddot{O} Z$

Sedef hastaliğr, aşır patolojik özelliklere ve tedavisinin farmakolojik olarak yetersiz kaldiğ çok sistemli bir otoimmün hastalik olan kronik inflamatuar bir hastalıktır. Temelinde sedef hastalığı epidermal hücreler, keratinosit hiperproliferasyonu, inflamasyon, dermal kapiller genişleme ve pro-anjiyojenik mekanizmalarla ilişkilidir. Diğer kronik hastaliklarla karşzlastırildiğında, sedef hastaliğg olan hastalar ciddi psikolojik strese ve bilissel işlev bozukluklarna sahip olmakla birlikte daha az fiziksel aktivite ve düşük kaliteli yaşam sürer. Patofizyoloji, sedef hastalı̆̆ının neden olduğu iltihaplanmanin artmasinda ve lokalizasyonunda önemli bir rol oynayan interlökin- (IL) -17, IL-23, tümör nekroz faktörü-alfa

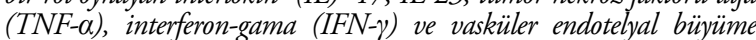
faktörü (VEGF) gibi çesitli aracıların katılımıyla karmaşıktır. Bununla birlikte, sedef hastalĭğ patofizyolojisi hakkında kesintisiz bilgi edinmek, sedef hastaliğmin kişiye özgü tedavisinin zorluklarmm üstesinden gelmek için kesfedilebilecek yeni terapötik hedefleri belirlememize olanak tanır. Geleneksel tedavide kortikosteroidler, vitamin-D, metotreksat ve siklosporin kullamulir, ancak bu ilaçlar düsük etkinliğe ve ciddi yan etkilere sahiptir ve bazen hastallk komorbiditelerine neden olur. 20162019 yillarn arasinda FDA tarafindan onaylanan risankizumab-rza, guselkumab ve tildrakizumab-asmn, gibi IL-23 blokerleri, brodalumab ve ixekizumab gibi IL-17 blokerleri ve TNF- $\alpha$ yn hedefleyen sertolizumab pegol gibi hedefe yönelik yeni biyolojikler, orta ila şiddetli sedef hastalığının tedavisinde devrim yarattr, ancak bu ilaçlarin düsük hasta uyumuna yol açan birçok yan etkiye sahip olduklan bildirildi. Ters biyoloji mühendisliği ile tasarlanan adalimumab, etanersept ve infliksimab biyobenzerleri de maliyet-etkin olmalar nedeniyle popüler hale gelmektedir. İlaçlarn yeniden kullanılması, esas olarak eski ilaçlar için yeni tıbbi kullanımlarn tanımlanmasına odaklanmaktadır. İlacın yeniden kullanılmasının ana odağı, ilaç molekülünün çeşitli hedeflerle nasil etkileşime girdiği ve farmakolojik etkisini nasil gerçekleştirdiği ve düşük toksisiteli etkili terapötik ajanlar tasarlamanın yeni olanaklarmı ortaya çıkarmasıdır.

Anahtar kelimeler: Sedef hastaliğg; İlaçların yeniden kullanılmasi; Damarlanma; Vasküler endotelyal büyüme faktörü; Keratinosit proliferasyonu, TNF- $\alpha, I F N-\gamma$, Th-17/Th-23 yolağg.

Received: 28.11 .2020

Revised: 09.04.2021

Accepted: 27.05.2021

ORCID: 0000-0002-6620-9558, Amity Institute of Pharmacy, Lucknow, Amity University Uttar Pradesh, Noida, U.P. India

" ORCID: 0000-0001-7646-642X, Amity Institute of Pharmacy, Lucknow, Amity University Uttar Pradesh, Noida, U.P. India 


\section{INTRODUCTION}

Psoriasis is a chronic inflammatory skin disease with a strong genetic predisposition and autoimmune pathogenic traits. Prevalence is nearly 2 to $3 \%$ of the world population (Affandi, 2018). The disease is characterized by epidermal hyperproliferation, hyperkeratosis, parakeratosis, dermal capillary dilation, and inflammatory cell infiltration (Krueger and Bowcock, 2005). The skin of the psoriasis patients is well-demarcated, locates with silvery scales, erythematous oval plaque formation. The formation of scales is due to the hyperproliferation of epidermal tissue with unmatured keratinocytes and incomplete keratinization with the detainment of nuclei in the stratum corneum. The basal keratinocytes undergo rapid mitosis compared to the usual mitosis process, which results in the thickening of the epidermis with combined dermal inflammatory infiltration. The infiltrate comprises neutrophils, macrophages, dermal dendritic cells, and $\mathrm{T}$ cells in the dermis (Lowes, 2014). The lesions appear red due to the high torturing of capillaries reaching the skin through a thin epithelium. Cytokines such as interferons (IFNs), tumor necrosis factor-alpha (TNF- $\alpha$ ), interleukin (IL)-12/IL-23, IL-9, IL-17, IL-22, typical inflammatory chemokines like chemokine (C-C motif) ligand (CCL)- 2, CCL3 and CCL5, chemokine (C-X-C motif) ligand (CXCL)-1, CXCL2 and CXCL8, and angiogenic growth factors are blameworthy factors exchanged between immune cells and keratinocytes that result in epidermal hyperplasia (Martin, 2012). Compared with other chronic diseases such as cardiovascular diseases, cancer, psoriasis patients have severe psychological stress and undergo reduced physical activeness (Rieder, 2012) and experience a low-quality life because of the low levels of employment.

\section{PATHOPHYSIOLOGY}

The pathophysiology of psoriasis (Figure 1) has been understood significantly in the last ten years by several research discoveries that have resulted in effective targeted therapy. T cells are believed to be key players in initiating and progressing pathological changes. The dendritic cells in the skin activate and catch a cutaneous antigen, which leads to migration to lymph nodes where they stimulate $\mathrm{T}$ cells by presenting them with antigen. This triggers the proliferation of antigen-recognizing T cells (Coimbra, 2012). Psoriasis is also named T-cell helper 1 (Th1) disease because of the predominance of Th1 pathway cytokines, such as TNF- $\alpha$, IFN- $\gamma$, IL-2 IL-12 in psoriatic plaques (Griffiths and Barker, 2007). The severity of psoriasis correlates with increased levels of Th1 cytokines in serum and circulating levels of TNF- $\alpha$, IFN- $\gamma$, IL-2, and IL-18. Th1 cells, dendritic cells (DCs), and natural killer (NK) cells secrete IFN- $\gamma$, accelerating the migration of immune cells towards the skin, activating monocytes, macrophages, DCs, and endothelial cells that stimulate epidermal cell proliferation, inhibiting apoptosis of keratinocytes. TNF- $\alpha$ is also an essential cytokine of the Th1 pathway and has proinflammatory effects. It is produced by DCs, $\mathrm{T}$ cells, macrophages, and keratinocytes. It also induces IL-6 and C-reactive protein (CRP) expression in psoriasis (Coimbra, 2012). IL-18 is expressed due to TNF- $\alpha$, which gives a solid chemotactic signal for raising neutrophils' levels. TNF- $\alpha$, with the help of IFN- $\gamma$, promotes the skin's inflammatory cell infiltration by improving the expression of Intercellular Adhesion Molecule-1 (ICAM-1) encoded by the ICAM1 gene. IL- 12 produced by DCs plays a vital role in the growth of T-helper type 1 cell-mediated immune response. Simultaneously with IL-12 from T cells, cytokines control the transcription of IFN- $\gamma$ and TNF- $\alpha$. IL-12 is responsible for the differentiation, proliferation, and maturation of $\mathrm{T}$ cells into memory effector cells.

A new paradigm of the Th17 pathway associated with IL-23 and IL-17 makes the pathogenesis more complicated (Lowes, 2013; Mudigonda, 2012). Ac- 
tivated DCs in the dermis produce IL-23 and IL-12, which lead to stimulation of Th17, Th22, and Th1 cells. IL-23-activated Th17 cells have IL-17A and IL17F. The stimulated epidermal cells produce an abundant number of cytokines and inflammatory mediators like IL-8, CCL-2, CCL- 20, and CXCL-3, in which CXCL-1, CXCL-2, and CXCL-5 are ligands. Vascular endothelial growth factor (VEGF) induces vascular dilation and hyperplasia, whereas activation of the keratinocytes also induces IL-17C, further perpetuating the inflammatory cycle (Lowes, 2013).

The earlier observations suggested that the involvement of immune response is required for the disease's progression, which in turn is associated with increase in the number of inflammatory infiltrates (Bos, 1989; Bos, 1983). Further studies revealed that the infiltrate in skin lesions contains large amounts of CD4+ and CD8+ T cells (Bos, 1989; Chang, 1994). The inhibition of active T-cells using IL-12 and diphtheria toxin fragment DAB389IL-2 proved that the T cells are involved in psoriasis' pathogenesis (Gottlieb, 1995).

Various human fusion proteins targeting the immune response in lesional skin, such as abatacept, which inhibits the naïve $\mathrm{T}$ cell activation (Iannone and Lapadula 2012), alefacept, which inhibits Cluster of Differentiation (CD2) co-stimulatory pathway and targets memory $\mathrm{T}$ cells (Mease, 2006; Iannone, 2012)and efalizumab, which is a subunit of lymphocyte-associated antigen that blocks lymphocyte activation (Livertox: Clinical and Research Information on Drug-Induced Liver Injury, 2012) resulted in a decrease in the progression of psoriasis and established the role of $\mathrm{T}$ lymphocytes in pathogenesis. The T lymphocytes' prominent pathogenic role in the psoriasis patients and several observations evaluated that the disease originated in familial groups (Farber, 1974; Brandrup, 1982) that concludes that it is an autoimmune state with a well-built genetic base. So, psoriasis's pathophysiology has several factors like the response of the immune system, psoriasis associated susceptible locus, auto-antigens, and various environmental factors, which made it more complex and challenging to understand. However, acquiring uninterrupted knowledge of psoriasis pathophysiology allows us to identify the novel therapeutic targets, which will help us overcome personalized psoriasis treatment challenges. 


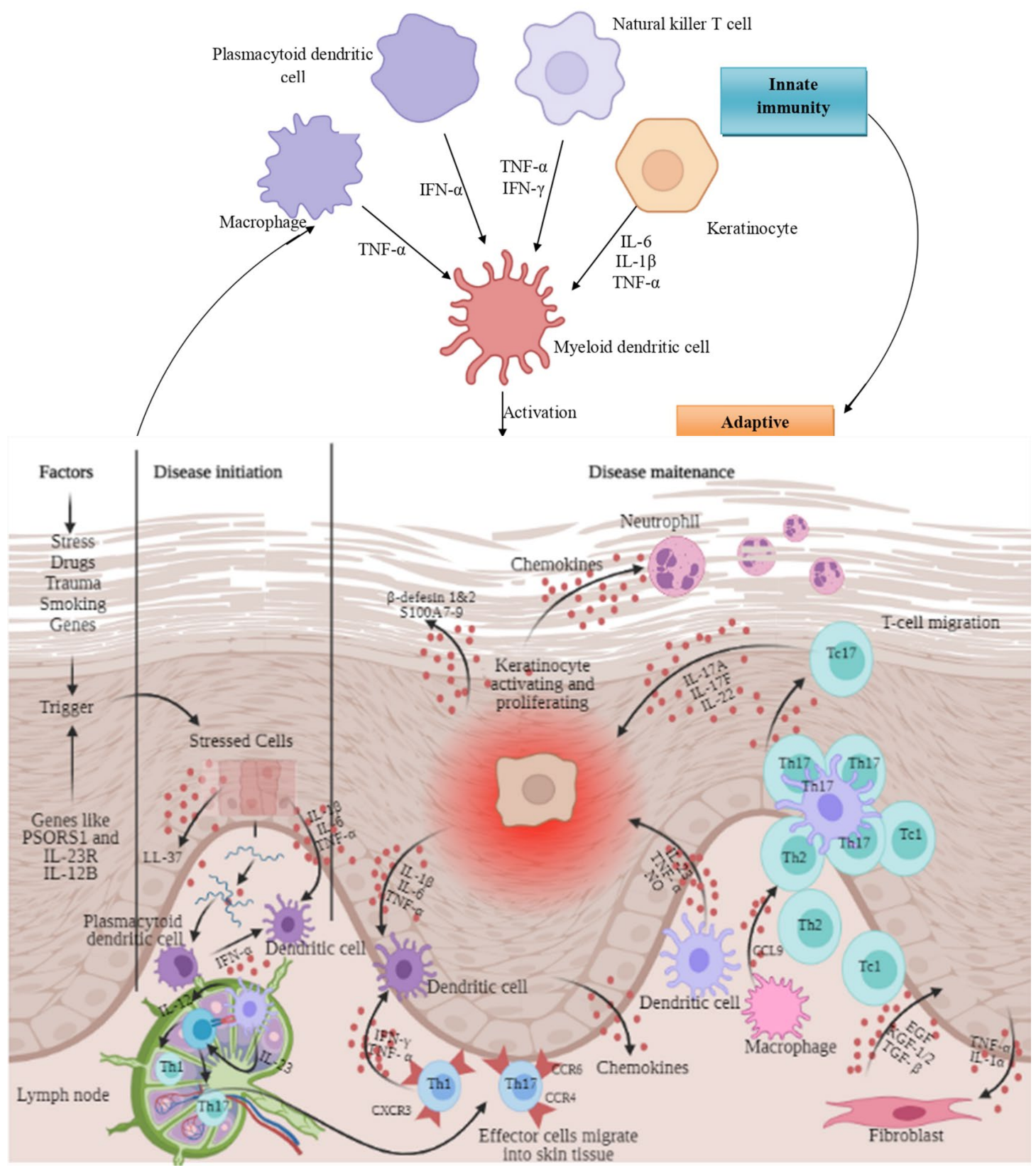

Figure 1. Pathophysiology of psoriasis 
EXISTING THERAPIES AND RECENT ADVANCES IN TREATMENT

The treatments available to date are to manage the occurrence of symptoms and control the disease's development. Conventional treatment of psoriasis includes topical, systemic, and intra-lesional therapies, which are corticosteroids, vitamins, phototherapies, systemic immunosuppressants, and biologics (Smith, 2006).

Conventional therapy includes corticosteroids, vitamin-D, anthralin, coal tar, retinoids, methotrexate, and cyclosporine. The main goal is to strive for normal conditions and maintain the quality of life. Corticosteroids treat mild to moderate psoriasis by slowing down the cell change by vanquishing the immune system leading to a downfall in inflammation and itching (Schlager, 2016). Vitamin-D analogs, namely, calcitriol and calcipotriene, are essential as an alternative for corticosteroids and bind to cytoplasmic vitamin $\mathrm{D}$ receptor, translocate into the nucleus, and bind to the nuclear receptor, and stimulates the transcription of vitamin $\mathrm{D}$ responsive genes, which regulate cell differentiation and down-regulate cell proliferation and inflammatory processes (Kragballe, 1995). Anthralin (dithranol) induces the release of reactive oxygen species, which has a suppressed effect on the hyperproliferation of keratinocytes and the alteration of leucocytes (Dogra and Kaur, 2010). Coal tar is used as monotherapy, combined with topical agents, systemic agents, and phototherapy. Skin becomes more sensitive to UV light by the occurrence of polycyclic aromatic hydrocarbons in coal tar (Thami and Sarkar, 2002). Retinoids are used as supportive therapy in chronic plaque psoriasis and mainly pustular psoriasis. It is trusted to regularize DNA activity in skin cells and reduce inflammation (Samarasekera, 2012; Kuijpers, 1997).Methotrexate, an immunosuppressive agent, antimetabolite, and a dihydrofolate reductase inhibitor, is effective in treating psoriasis (Salim,
2006). Cyclosporine, a calcineurin inhibitor that binds to cyclophilin, initiates immunosuppression by stopping ulterior T-cell activation from treating moderate to severe psoriasis (Colombo, 2013). Phototherapy is employed for patients who do not respond to topical therapies and $20 \%$ or a significant part of body surface with plaques of psoriasis; it is believed that this leads to programmed cell death with increased transcription and expressing the IL-10 in keratin cells (Camisa, 2000). Ultraviolet A radiation (UVA) in association with systemic psoralens (PUVA) effectively treats skin lesions. Ultraviolet B (UVB) combined with coal tar or anthralin effectively treats moderate to severe psoriasis (Greaves, 1995). Nevertheless, conventional systemic therapies for psoriasis have not entirely fulfilled the patients' requirements regarding minimizing the severity of symptoms, cumulative toxicity of target organs, and potential drug interactions (Nijsten, 2005). Christophers et al. reported that nearly 50 percent of the patients found themselves highly unsatisfied in the patient, perceptive population study (Christophers, 2013). Lebwohl et al. reported that psoriasis management when associated with psoriatic arthritis, is worse, and 53 percent of the patient population rated as suffering from the severity of psoriasis (Lebwohl, 2014).

The treatment approaches for psoriasis included the antibody and fusion protein-based to selectively target the central mediators of inflammation (Lowes, 2007; Granstein, 2001; Kupper, 2003). Biological agents are primarily proteins, very unique as they are obtained from living organisms. Biological therapies are innovative therapeutic options for moderate to severe psoriasis that have fewer side effects when compared to conventional therapies. Hepatotoxicity, nephrotoxicity, and bone marrow suppression are serious adverse effects of traditional drug molecules, which can be avoided by biological therapies with particular molecular targets (Rahman, 2012; Krueger, 2001; Spitaler, 2004). 
Nevertheless, biological therapy is a treatment that involves the patient's innate immune system to treat the disease and protect from different adverse effects. Still, it is also causing diverge adverse effects, including hypersensitive infections, various dermal infections, and proliferation (Rich, 2004).

Biologicals have been classified based on mechanism of action (Sterry, 2004) and are very effective in treating psoriasis. The main classes are biological agents targeting cytokines and $\mathrm{T}$ cells. The cytokine-targeted therapy includes anti-TNFs (infliximab, etanercept, and adalimumab) and a monoclonal antibody targeting IL-12 and IL-23 (ustekinumab). T cell-targeted treatment includes efalizumab and alefacept. Efalizumab is a monoclonal antibody that inhibits lymphocyte interaction-function-associated antigen-1(LFA-1) with ICAM-1, which disrupts $\mathrm{T}$ cells' connection with dendritic cells at lymph nodes and tissues (Guttman-Yassky, 2008).

Immunopathology-based treatments raised the idea of novel biologics. The main aim is to be more selective and intervening immunologically, hoping for lesser adverse effects than traditional medicine (Krueger 2002). These novel biologicals act by varied mechanisms such as

1. Blocking the release of cytokine and migration of antigen-presenting cells (APC)

2. Targeting activated $\mathrm{T}$ cells and controlled further T-cell activation,

3. Inhibiting TNF- $\alpha$.

4. Inhibiting the differentiation of the activated $\mathrm{T}$ cells into Th1 and Th17 cells.

5. Inhibiting cytokines like IL-17.

\section{DRUG REPURPOSING}

Drug repurposing is an exciting and sensible drug development process which it is economical and time-saving and focuses mainly on re-finding new medical uses for old drugs. There are many positive attributes of drug repurposing (Breckenridge, 2019) as summarized below:

1. Unlike normal drugs, repurposed drugs have fewer chances of failure in the safety and efficacy trials.

2. The period for drug development is less than the actual process as it has already been tested pre-clinically for safety.

3. The investment is low and is depended on the drug development process and the stage in which the candidate drug is present.

These advantages give strength to obtain a less risky result and gaining a fast return on investment. Finally, the repurposed drug results in exploiting the novel targets and emerges with new pathways for drug action. From the very beginning, drug repurposing has been a serendipitous and opportunistic approach. Several drugs like zidovudine, sildenafil, thalidomide, and rituximab were approved for a particular indication but surprisingly paved the way to new indications.

For decades, dermatologists and researchers at the cellular and molecular levels have improved the concept of psoriasis' immunopathogenesis. The immuno-pathological basis of psoriasis demands targeted drug therapy for its complete cure, such as biologicals, small molecule inhibitors, kinase inhibitors, and phosphodiesterase inhibitors. Though biologicals have been a good option for targeted therapy, they also resulted in potential side effects of dermatological interventions. The prospective capture registry reported that females are not (less) satisfied with the biological treatment, and they are experiencing more side effects than males (van der Schoot, 2019). So the instant answer will be that the drug repurposing strategy can be redirected towards the novel targets for treating psoriasis entirely. There is the most critical requirement of novel and effective treatments for psoriasis. 
Alefacept, denileukindiftitox, and etanercept are recently approved drugs by the United States Food and Drug Administration (US-FDA). Some of the biologicals, such as basiliximab (Nashan, 1997), daclizumab, and siplizumab, are under various stages of clinical trials.

Alefacept is a fusion protein, the extracellular domain of LFA- 3 fused with the $\mathrm{CH} 2$ and $\mathrm{CH} 3$ domains of IgG1. It competitively binds to $\mathrm{CD} 2$ on $\mathrm{T}$ cells to block its activation, and it was the first biological agent to be approved for the treatment of psoriasis (Ellis, 2001). A clinical trial with 507 patients was conducted to check the efficacy of alefacept in chronic plaque psoriasis patients, 168 out of 507 patients were considered placebo group, and the rest of the patients were administered weekly $10 \mathrm{mg}(\mathrm{n}=173)$ or $15 \mathrm{mg}$ ( $\mathrm{n}=166)$ alefacept intramuscularly. After the clinical response was checked, it was reported that there was a 41 percent reduction in the severity of symptoms in the $10 \mathrm{mg}$ group, 46 percent reduction in the severity of symptoms in the $15 \mathrm{mg}$ group, and 25 percent reduction in the placebo group (Ortonne, 2003). Denileukindiftitox is a fusion toxin made from the IL-2 gene and the enzymatically active ADP-ribosyltransferase domain of diphtheria toxin. It acts on the IL-2 receptor and decreases the number of pathogenic T-cells (Foss F, 2000). Etanercept is a fusion protein composed of two TNF receptors, which are fused to the Fc portion of the human IgG antibody. It shows action against exogenous TNF receptors preventing an excess of TNF binding to cell-bound receptors, resulting in a reduction in the amount of active TNF and mitigation of TNF-mediated diseases (Goffe, 2003). Basiliximab is a chimeric monoclonal antibody directed against the CD25 subunit of IL-2 and decreased the number of pathogenic T-cells (Owen, 2000). Clinical trials evaluated the effectiveness of basiliximab in treating psoriasis. Several clinical studies reported that it effectively treats severe psoriasis, which is very difficult to manage (Owen,
2000; Mrowietz, 2000; Salim, 2000). Daclizumab is a humanized monoclonal antibody. It is FDA approved for acute renal transplant rejection and is currently under evaluation to treat psoriasis (Krueger, 2000). It acts against CD25 and deactivates the T-cell. Still, no adverse effects associated with the use of daclizumab are known. Therefore, it acts as an effective therapy for patients with moderate to severe psoriasis (Krueger, 2000). Siplizumab, a humanized IgG1 monoclonal antibody, is directed against $\mathrm{CD} 2$ and decreasing the number of pathogenic T-cells. Currently, it is crossing the phase II stage, but no severe adverse reactions were noted; multiple courses of siplizumab may be an effective therapy for psoriasis(Langley, 2010).

TNF- $\alpha$ is a proinflammatory cytokine found in increased concentration in the joints and skin. Endogenous skin cells and activated leukocytes secrete TNF- $\alpha$, which binds to the target receptor and plays an active role in leukocyte recruitment, migration, and activation, resulting in the secretion of more cytokines which induce an inflammatory cascade. The biological agents that block TNF-ainclude etanercept, infliximab, and adalimumab. Infliximab and adalimumab are monoclonal antibodies that act directly against TNF- $\alpha$ (Winterfield, 2004; Richard, 2009). Briakinumab (ABT874) is a fully human monoclonal antibody. It acts against psoriasis by targeting on P40 subunit of IL-12 and IL-23. The resulting downstream T-cell signal prevents IL's binding with T-cell (Kimball, 2008).

\section{THERAPEUTIC TARGETS}

Treating epidermal hyperplasia resulting from abnormal proliferation and differentiation of basal keratinocytes is mainly focused on psoriasis therapy. Infiltration and accumulation of leukocytes in T lymphocytes route epidermal hyperplasia and neoangiogenesis(Christophers, 2001). 


\section{Keratinocytes}

Therapies targeting hyperproliferation include newer analogs such as tacalcitol and maxacalcitol that have the same effects as calcipotriol on normal human keratinocyte proliferation and differentiation (Bos, 1989). Bexarotene, a retinoid X receptor-specific retinoid indicated for second-line treatment of cutaneous $\mathrm{T}$ cell lymphoma, also has antiproliferative effects in psoriatic skin (Wingren, 1995). Troglitazone, a thiazolidinedione, predominantly activates the g-subunit of the peroxisome proliferation activation receptor (PPAR) and promotes ex vivo differentiation of cultured normal and psoriatic keratinocytes (Stuart, 2002). Mainly PPAR- $\alpha$ and PPAR- $\gamma$ agonists are remarkably reducing keratinocytes' proliferation without prompting terminal differentiation (Elder, 2010). Genetic research advancements are resulting in antiproliferative targets. A member of the short-chain dehydrogenase reductase family, the $h R D H$-E2 gene is expressed abundantly in psoriatic tissues (de Cid, 2009). More efforts must be focused on the role of transcription factors that help a better understanding of the paracrine regulation of keratinocyte differentiation and hyperproliferation.

\section{Neuropeptides}

The immune system governs the pathophysiology of psoriasis. At the same time, the underlying inflammatory process is maintained by the nervous system that primarily involves neuropeptides such as gene-related peptide, nerve growth factor, vasoactive intestinal peptide, substance $\mathrm{P}$, adenosine, glucagon-like peptide, somatostatin, and pituitary adenylate cyclase polypeptide, which induces neurogenic inflammation in psoriatic patients(Vidal Yucha, 2019). The functions of the neuropeptides are the promotion of keratinocyte hyperproliferation(Haegerstrand, 1989), induction of the secretion of IL-6, and IL-17A that increases the involvement of Th 17 leading to the progression of inflammatory skin diseases like psoriasis (Yadav, 2008), and induction of Langerhans antigen-presenting cells to Th cells (Ding, 2016). The sensory nerve stimulations in response to the external environment make the cutaneous nerves secrete the neuropeptides that engage the inflammation, dilate the blood vessels, and activate the keratinocytes to generate the inflammation (Kodji, 2019; Mehta, 2019). The elevation of the number of cutaneous nerve fibers increases the secretion of NGFs mutually promotes inflammation and intensifies psoriasis' progression (Mehta, 2019). When various reports of normal skin and nonlesional psoriatic skin were examined and compared, increased expression of substance $\mathrm{P}$ was observed in psoriasis skin (Chan, 1997). Also, when reports of psoriatic pruritus patients and psoriasis patients with no pruritus were compared, the expression of substance $\mathrm{P}$ in keratinocytes was higher in patients with pruritus (Chang, 2007). The skin of psoriasis patients is represented with high mast cells. For example, in atopic dermatitis (Nakamura, 2003), substance P provokes mast cells' degranulation and enhances the production of histamine and other inflammatory substances. The maturation of Th1 and Th17 is promoted by TNF- $\alpha$, while dendritic cells produce IL-23 (Asarch, 2008). Many drug discovery teams' contribution towards an understanding of neuropeptide biology is exemplary, but to date, drugs selectively binding with neuropeptide receptors have not emerged from the clinic.

\section{Angiogenesis}

Endothelial growth factor (VEGF), platelet-derived growth factor, fibroblast growth factor (FGF), transforming growth factor (TGF)- $\alpha$ and $-\beta$, TNF- $\alpha$, ILs, chemokines, angiogenin, and angiopoietins are the significant angiogenesis inducers while anti-angiogenic like endostatin, angiostatin, and thrombospondin act against it. Disturbance leads to dysregu- 
lated and uncontrolled angiogenesis, which has been implicated in causing an increment in endothelial cell proliferation in the outermost capillary plexus and expanded dermal microvasculitis (Lebwohl, 1997, Cantatore, 2017) as seen in psoriatic arthritis.IL-1 inhibitors (anakinra), TNF- $\alpha$ inhibitors (infliximab, adalimumab, etanercept, golimumab, and certolizumab), IL-6 blockers (tocilizumab), anti-IL-17 antibodies (secukinumab), anti-IL-12/23 antibodies (ustekinumab), anti-CD-20 antibodies (rituximab), anti-Bcell activating factor (belimumab), and anti-CD80 and anti-CD86 receptors (abatacept) are some of the promising angiogenesis inhibitors that can benefit patients of psoriatic arthritis (Cantatore, 2017).

Stimulated keratinocytes in epidermal lesions become a significant source of pro-angiogenic mediators. Matrix metalloproteinases (MMPs) (Seville, 1976), vascular endothelial growth factor (VEGF) (Farkas, 2001), integrins (Allen \& Bloxham, 1989), and angiopoietin are angiogenic molecules that cause psoriasis (Williams, 1992). Vascular endothelial growth factor shows a prominent pathogenic role in psoriasis. Clinical studies have revealed an increase of VEGF in lesions (Shah, 2007); serum VEGF levels and disease severity are associated with each other (Weinstein, 1997). Mice expressing high VEGF in epidermal lesions developed a phenotypic character resembling psoriatic lesions with the restrainment of $\mathrm{CD} 8+$ and CD4+ T lymphocytes in the epidermis and dermis, respectively (Scher, 2001). Many reports in the literature indicate that angiogenesis plays a remarkable role in psoriasis' pathophysiology; however, limited information is available on the success of anti-angiogenic therapies. Methotrexate, psoralen, and ultraviolet light A (PUVA) mainly target the T cell-mediated immunopathology of psoriasis; both have been shown to possess significant anti-angiogenic effects in psoriatic patients (Shaker, 2013). Schonthaleret al (2009). report the clinical benefit of Anti-VEGF monoclonal antibody G6-31in an experimental model of psoriasis in mice.

\section{Cytokine antagonists}

\section{Anti-TNF- $\alpha$ agents}

TNF- $\alpha$ is the crucial effector cytokine in inflammatory diseases like psoriasis. TNF therapies have been used for treating various inflammatory disorders, such as rheumatoid arthritis, inflammatory bowel disease, and psoriasis (Taylor, 2001). $100 \mathrm{mg}$ weekly dose of etanercept resulted in PASI75 in Phase III studies at 12 th week in $47-49 \%$ patients compared with placebo. It is a recombinant human TNF-receptor fusion protein that was the first TNF- $\alpha$ inhibitor approved in 2004 to treat psoriasis (Tyring, 2006). Infliximab is a chimeric monoclonal antibody showing anti-TNF activity with a high degree of affinity and specificity (Schopf, 2002). Infliximab administered intravenously at a weekly dose of $5 \mathrm{mg} / \mathrm{kg}$ (on 0 th, 2nd, and 6th week) resulted in PASI75 responses at week 10 of $75.5 \%$ and $80 \%$ compared with placebo in two phases III studies as reported by Menter et al. (2007) and Reich et al. (2005), such promising outcome was not reported before with any other therapy. Adalimumab is a human monoclonal antibody of the IgG1 isotype similar to infliximab approved in 2005 for treating psoriasis. Rønholtand Iversen (2017) report 70\% PASI75 response rates in psoriatic patients in a clinical trial. Though infliximab is more efficacious than adalimumab, its side effects limit its use in psoriatic arthritis; therefore, adalimumab is preferred as first-line therapy (Smith, 2017).

Golimumab is a human recombinant immunoglobulin G1 monoclonal antibody, and it directly targets TNF- $\alpha$ (Urdaneta, 2017). Certolizumab pegol is an anti-TNF- $\alpha$ biologic; its safety and efficacy were evaluated by a dose-response, randomized, placebo-controlled double-blind clinical study (NCT00245765). It was well tolerated with zero safety 
concerns. It does not provoke an antibody-dependent cytotoxic reaction, as evident with the TNF- $\alpha$ blockers because it does not possess fragments crystallizable $(\mathrm{Fc})$ region (Reich, 2012).

Development of neutralizing anti-drug antibodies (Kui, 2016), lupus, multiple sclerosis, congestive heart failure, opportunistic tuberculosis are some of the severe but rare adverse effects characteristics of anti-TNFa therapies which are being continuously and persistently pursued their development as more effective and targeted therapeutic agents with minimum side effects (Reid, 2020).

\section{Anti-IL-17 and anti-IL-12/23 agents}

Researchers strongly believe that the IL-23/TH17 cell pathway plays a highly significant role in psoriasis progression; therefore, the therapies being developed are focused on ways of IL-23 or IL-17 cytokine signaling (Reid, 2020) (Table 1). Diverse IL-17 inhibitors are being investigated for psoriasis. Secukinumab, Brodalumab, and Ixekizumab are fully humanized immunoglobulin G1, G2, and G4 monoclonal antibodies, respectively, which normalize IL-17A (Gordon, 2016; McInnes, 2018). Brodalumab additionally blocks IL-17F also. Though clinical trials have not been conducted, antibody RG7624, targeting IL-17A and IL-17F for chronic inflammation, is reported (Miossec, 2012). IL-12 and IL-23 have a similar p40 subunit that is bounded to receptor IL-12R $\beta 1$ on the cell surface. Ustekinumab, an anti-p40 antibody that binds to the p40 subunit of IL-12 and IL-23, disturbs cell signaling mediated by IL-12 and IL-23 (Papp, 2013). On the other hand, a long-term safety study reported that it does not cause dose-related or cumulative toxicity has the most acceptable results when compared with adalimumab and etanercept infliximab. Tildrakizumab and Guselkumabare G1 monoclonal antibodies target the IL-23 p19 subunit (Papp, 2015; Reich, 2017). Risankizumab selectively targets IL-23A (Papp, 2017).

Table 1. List of anti-IL-17/23 biologics

\begin{tabular}{|c|c|l|}
\hline Biologics & Nature of the biologic & Mechanism of action \\
\hline $\begin{array}{c}\text { Secukinumab } \\
\text { Gordon, 2016; McInnes, 2018) }\end{array}$ & G1 monoclonal antibody & $\begin{array}{l}\text { Selectively binds to the IL-17A cytokine and inhibits its } \\
\text { interaction with the IL-17 receptor }\end{array}$ \\
\hline $\begin{array}{c}\text { Brodalumab } \\
\text { (Miossec and Kolls, 2012). }\end{array}$ & G2 monoclonal antibody & Inhibits the IL-17 receptor \\
\hline $\begin{array}{c}\text { Ixekizumab } \\
\text { (Gordon, 2016; McInnes, 2018). }\end{array}$ & G4 monoclonal antibody & $\begin{array}{l}\text { Selectively binds to the IL-17A cytokine and inhibits its } \\
\text { interaction with the IL-17 receptor }\end{array}$ \\
\hline $\begin{array}{c}\text { Ustekinumab } \\
\text { (Papp, 2013) }\end{array}$ & Anti-p40 antibody & Disturbs cell signaling that is mediated by IL-12/ IL-23 \\
\hline $\begin{array}{c}\text { Tildrakizumab } \\
\text { (Papp, 2017, Reich, 2017) }\end{array}$ & G1 monoclonal antibody \\
\hline $\begin{array}{c}\text { Guselkumab } \\
\text { (Papp, 2017, Reich, 2017) }\end{array}$ & $\begin{array}{l}\text { The targets p19 subunit of IL-23 and also blocks the } \\
\text { release of IL-17 and TNF- } \alpha\end{array}$ \\
\hline $\begin{array}{c}\text { Risankizumab } \\
\text { (Papp, 2017) }\end{array}$ & $\begin{array}{l}\text { Prevents the binding of the cytokines IL-23, IL-43 with } \\
\text { its receptor }\end{array}$ \\
\hline
\end{tabular}




\section{Small molecule inhibitors}

\section{Anti-Janus kinase agents}

Various inflammatory cytokines such as IL-23 bind to both type one and two cytokine receptors, leading to Janus kinase (JAK) stimulation -mediated signaling intracellularly (Schwartz, 2017). The JAKs undergo dimerization and form heterodimers, thus modifying the receptors for allowing signal transducer and activator of transcription (STAT) proteins to bind and get activated. After the STAT proteins get started, they dimerize and regulate the gene transcription by translocating to the cell nucleus (Hsu \& Armstrong 2014). So inhibition of JAKs, in turn, inhibits the signaling pathway and gene transcription as well as inflammatory cytokine production, thus minimizing the inflammation.

JAK inhibitors give favorable treatment results in psoriasis patients. Inhibition of lymphocyte infiltration, STAT3 phosphorylation, and keratinocyte proliferation in a mouse model of contact hypersensitivity is obtained by the topical application of JAK inhibitors (Fridman, 2011). Baricitinib is a novel and oral selective inhibitor for JAK1 and JAK2, and it is in the phase II trial with good results. Phase III trials can be an effective molecule for managing psoriasis (Papp, 2016). Tofacitinib is a dual inhibitor for JAK1 and JAK3 (Papp, 2016).

\section{Anti-A3 agents}

A3 adenosine receptor (A3AR) is a G-protein-coupled receptor family that regulates enormous intracellular signaling pathways. High expressions of A3AR are observed in lesioned cells and the peripheral blood mononuclear cells in psoriasis patients (Fishman \& Cohen, 2016). Down-regulating the activation of the NF- $\kappa B$ signaling pathway and promoting the programmed cell death of inflammatory cells is achieved by inhibiting the A3AR activation (Fishman, 2012). Piclidenoson [generically known as IB-MECA (meth- yl 1-[N6-(3-iodobenzyl)-adenin-9-yl]-b-D-ribofuronamide]/CF101, an adenosine $\mathrm{A} 3$ receptor inhibitor and a novel anti-inflammatory agent, is currently under phase III clinical trial in patients with moderate to severe plaque psoriasis(Rønholt and Iversen, 2017) the effect is being compared with apremilast in this study (Can-FiteBioPharma, NCT03168256). Phase II study revealed effective mitigation of disease symptoms indicating a direct correlation between $\mathrm{A} 3 \mathrm{AR}$ at baseline and patients' response to piclidenoson, suggesting that it can be used as a predictive biomarker (David, 2012).

\section{Anti-IкBלagents}

$\mathrm{I} \kappa \mathrm{B} \zeta$ protein is a third member of the nuclear I $\mathrm{KB}$ family of proteins expressed in undetectable concentration in resting cells except in keratinocytes and several mucosal tissues. Its expression is induced by stimulation of Toll-like receptors (TLR) 2, 4,5, 7, and 9. IL-1 $\beta$ is also reported to cause $\operatorname{I\kappa B} \zeta$.I $\mathrm{I} B \zeta$ is an inherent part of the immune system and remarkable regulator of inflammation, cell proliferation, and survival (Willems, 2016). Though the molecular mechanism and regulation of I $\kappa$ B $\zeta$ by the IL-17A pathway is unclear, it plays a significant role in psoriasis by IL17A driven mechanisms. Johansen et al. (2015) have established that $\mathrm{I} \kappa \mathrm{B} \zeta$ plays a crucial role in psoriasis development. Bertelsen et al., 2020 have reported thatI $\mathrm{B}$ לplays a significant role in the antipsoriatic effect of secukinumab, which was tested on 14 patients with plaque psoriasis. It was shown to improve clinical scores, histologic psoriasis features and alter the skin transcriptome.

\section{Bioinformatics - machine learning approach}

The bioinformatics machine learning approach using a letter embedding method helps predict the drugs that can be repurposed with different gene targets for psoriasis. It brings a confirmation regarding the drug candidates that are effective in treating pso- 
riasis, identifying the potent drug candidates being used in the treatment of other inflammatory diseases that could also be repurposed for psoriasis. The drug targets that were predicted by this approach have improved the understanding of notable characteristics of genes that were differentially indicated in the lesioned skin. Along with budesonide (a corticosteroid that is being used for inflammatory bowel disease and asthma) and hydroxychloroquine (an anti-malarial drug that is being used for rheumatoid arthritis) in combination with balsalazide and mesalamine(which have anti-inflammatory activity) could be a beneficial combination to treat psoriasis (Mason, 2002).

The drugs and their targeted genes that are essential components in the pathogenesis of psoriasis include $\mathrm{T}$ helper cell one induced cytokine IFN- $\gamma$, NOS2, a nitric oxide synthase that is involved in the anti-microbial activity (Quaranta, 2014), IL1B that causes hyperproliferative inflammatory lesions in different mice models (Schön, 2001). Drugs have various gene targets; cyclophosphamide, budesonide, and mercaptopurine have many gene targets 308,45 , and 35 , respectively (Table 2 ).

Table 2. Drugs and their targets

\begin{tabular}{|l|l|}
\hline \multicolumn{1}{|c|}{ Drugs } & \multicolumn{1}{c|}{ Gene targets } \\
\hline Budesonide & $\begin{array}{l}\text { CCL2, ABCB11, IL1 } \beta, \text { CYP3A4, CSF2, } \\
\text { CYP3A5, IFN- } \gamma \text {, BCL2 }\end{array}$ \\
\hline Hydroxychloroquine & NOS2, IL1B, CCL2 \\
\hline Mercaptopurine & BCL2, GATA3, SOD2 \\
\hline Mesalamine & IL1 $\gamma$, PPAR $\gamma$, BCL2, IFN- $\gamma$, \\
\hline Cyclophosphamide & $\begin{array}{l}\text { ESR1, CYP3A4, CSF2, CYP3A5, } \\
\text { GATA3, SOD2 }\end{array}$ \\
\hline Leflunomide & NOS2, CYP3A4, IL1 $\beta$, ESR1 \\
\hline Balsalazide & PPAR $\gamma$ \\
\hline Latanoprost & ACBC11 \\
\hline
\end{tabular}

Niclosamide: a promising candidate for repurposing

Niclosamide is an anti-helminthic drug with acceptable safety and efficiency and is being used for 50years (Hamdoun, 2017). The potent anti-inflammatory property of niclosamide targets the STAT3, NF- $\kappa B$, and NFATc-1 signaling paradigm with the less toxic indication in several in vitro and preclinical research. The static intracellular and molecular network gives pathological signs like hyperproliferation and chronic inflammation. This reasonable mechanistic relevancy gave rise to the idea of repositioning the niclosamide. It inhibits keratinocyte hyperproliferation by apoptosis through the loss of mitochondrial membrane potential, cell cycle arrest at the Sub G1 phase, and DNA fragmentation (Thatikonda, 2020). In the imiquimod (IMQ)- induced BALB/c mouse model, niclosamide persistently lessened the IMQ-induced hyperplasia and inflammation by downregulation of p65, STAT3, NFATc-1, and NF- $\mathrm{BB}$ transcription factors, including expression of Akt, Ki-67, and ICAM-1 proteins. Niclosamidewas also reported inducing apoptosis in keratinocytes.

\section{Bevacizumab as diminutive agent in psoriasis}

Anti-VEGF treatment for psoriasis is not much developed. VEGF is a well-identified growth factor that promotes angiogenesis, one of the pathogenic bases for psoriasis. Angiogenesis is involved in the pathology of various disorders such as psoriasis, cancer growth, rheumatoid arthritis, and metastasis. Bevacizumab, a humanized monoclonal antibody, is a clinically active antibody against diabetic retinopathy, several cancers with anti-VEGF activity (Wilson, 2004; Salesi, 2005). Though there is no therapeutic effect of bevacizumab in psoriasis, there is a correlation between disease severity and increased VEGF levels in plasma that caused chronic plaque psoriasis (Malhotra, 1989). Altering the VEGF levels in plasma could 
be a promising approach to treat psoriasis (Bhushan, 2002). Another anti-angiogenic molecule named neovastat (AE-941) that blocks VEGF and matrix metalloproteinase is under investigation to treat psoriasis (Salesi, 2005; Sauder, 2002). Matrix metalloproteinases play a crucial role in psoriasis pathology. They bring about structural changes of the epidermis by promoting angiogenesis in the dermal blood vessels and immune cell infiltration. During the disease eruption, they might get expressed differentially. Many clinical trials have investigated the mitigating effects of MMP inhibitors (MMPis) like neovastat, trocade, prinomastat, and tanomastat against psoriasis, but the majority of published results are not very encouraging. The MMPI's are reported to produce serious side effects like musculoskeletal pain and stiffness or ineffective. However, newer interest is focused on the utility of azasugars and phosphoramides as promising MMPis that might prove effective in treating psoriasis (Mezentsave, 2014).

Roflumilast- a phosphodiesterase-(PDE)-4 inhibitor

PDE-4 regulates the intracellular level of cyclic adenosine monophosphate (cAMP). PDE-4 is also a mediator of biological response towards extracellular provocation in many cells, including immune cells (Moustafa \& Feldman, 2014). The activity of PDE-4 is higher in lesional skin than in normal skin (Pincelli, 2018). The downregulation of TNF- $\alpha$, interferon- $\gamma$, IL-23/IL-17 can be achieved when PDE-4 is inhibited (Li, 2018). Apremilast is an oral formulated PDE-4 inhibitor that got approval for treating moderate-severe plaque psoriasis (Corporation, 2019). PDE-4 inhibitors that can act topically are still not approved to treat psoriasis. A daily once cream containing roflumilast, a PDE-4 inhibitor, with more water content and a cosmetic solvent named ethoxydiglycol is under investigation to treat plaque psoriasis. The phase II A trial conducted with 89 patients showed a favorable safety profile similar to the placebo with reduced severity and size of the psoriasis plaques (Lebwohl, 2020).

\section{Genetic targets of psoriasis}

Genome-wide association studies (GWAS) give a profound insight into the disease and further possibilities for the cure. The main target of the GWAS approach is identifying genetic targets and drugs for repurposing.

By exploring the GWAS catalog, 126 psoriasis-associated genes (PAG) were listed (Table 3). Sixty-eight genes obtained from canSAR protein annotation tool were found to be druggable. Various bioinformatics and proteomics tools were explored to extract and create a working list of PAG. The genomic, transcriptomic, proteomic, genetic, clinical, and functional annotation of these genes was performed using the Human gene database-GeneCards. This includes the two powerful tools GeneALaCart and GeneAnalytics. GeneALaCart provides methodical and comprehensive information of gene lists achieved from differential expression, transcriptional regulation, siRNA screens, or genome-wide genetic association studies (GWAS). In contrast, GeneAnalytics provides gene expression analysis and function-based analysis (Safran, 2010).

\section{Gene ontology (GO)}

It is a typical outline that defines the concepts used to describe the gene function, and it also provides the characterization of genes of a particular disease. Information about proteins, biological processes, cellular components, molecular procedures, pathways, and interactions was determined for each PAG from the GeneALaCart meta-analysis tool that leads to discovering super-pathways associated with psoriasis genes (Harel, 2009). Protein annotation describes the sites of interest and localization in the protein sequence, such as post-translational modifications, binding sites, and enzyme action, secondary 
and tertiary structure of different proteins. Chemogenomics analysis provides information on biological annotation, chemical screening, expression amplification, and 3D structural data (Halling-Brown, 2012). The PAG list is subjected to mutational and disorder analysis, and VarElect is an application used to prioritize the disease/phenotype-dependent gene variant (Papp, 2015). 30 genes out of 126 PAG were found to have an indirect association with mutational variants. Six genes were directly associated with various disorders, and 23 genes were indirectly related to different diseases. With the systematic screening of small molecules against the drug target families, it is possible to identify novel drug targets. Sixty-eight psoriasis proteins were revealed by the canSAR protein annotation tool that plays a crucial role in executing the drug action.

\section{NEW THERAPEUTIC STRATEGIES}

Drug repurposing and identifying novel targets should have an ideological approach that identifies the main loop causing the disease, which sets a central target for psoriasis treatment. A clear-cut understanding of essential pathways altered by the therapeutic interventions is also needed for interpreting the disease condition. Illuminating the molecular mechanisms of disease progression is the first important step for developing a novel psoriasis treatment strategy. Global transcriptomic profiling, omics technology has been used to understand the theory of molecular mechanisms associated with disease (Qu, 2012). Investigation and comparison of lesional skin (LS) to nonlesional (NL) skin by transcriptomics studies in patients with psoriasis to regular healthy volunteers (Kulski, 2005; Reischl, 2007; Yao, 2008; Nair, 2009; Swindell, 2011; Suárez-Fariñas, 2012; Bigler, 2013)gives a brief understanding of the main molecular mechanisms that are being involved in substitutive treatments (Zaba, 2009; Krueger, 2012). Another strategy is to evaluate the docile nature of biologics or small mol- ecules as it is evident that they have a specific target; they may intervene in gene targets.

Table 3. Super pathways under the control of psoriasis genes

\begin{tabular}{|c|c|}
\hline Various pathways & PAG \\
\hline Interleukin 3,5 signalling & $\begin{array}{c}\text { DDX58, STAT2, IL23R, } \\
\text { ELMO1, TSC1, TYK2, IFNLR1, } \\
\text { PSMA6, CAMK2G }\end{array}$ \\
\hline Cytokine signaling & IL13, IL23R, IFNLR1 \\
\hline Interleukin 11 signalling & TYK2 \\
\hline Apoptosis & IL13, PSMA6, TNIP1, TP63 \\
\hline TNFR1 signaling & ERAP1 \\
\hline The intrinsic pathway of \\
apoptosis & TP63 \\
\hline $\begin{array}{c}\text { Ubiquitin-dependent } \\
\text { degradation of cyclin }\end{array}$ & PSMA6 \\
\hline NF-kappa B signalling & DDX58, TNFAIP3 \\
\hline Interferon-gamma signalling & DDX58, STAT2, TYK2, \\
\hline CAMK2G
\end{tabular}

\section{CONCLUSION}

Psoriasis is an absurd, autoimmune, and multifactorial chronic inflammatory autoimmune disease with unresolved pathogenesis. It has a complex interplay between genetic inclinations, immune responses, and environmental triggers that play a crucial role in disease progression. Though psoriasis has multiple treatment options with real progress in controlling the disease, it has the limitation of severe side effects 
and life-long therapy, which makes the patient compliance and adherence to therapy difficult. Psoriasis needs persistent treatment with an ideal drug with excellent safety, efficacy, and compatibility profiles. Though a single drug cannot treat the disease's complete symptomology and underlying cause, the current stepwise approach to psoriasis treatment helps manage the disease and improve the lives of psoriatic patients. Topical therapy takes care of mild psoriasis, while conventional systemic and phototherapies are meant for moderate psoriasis. Severe cases are managed with small molecules and biologics. Biologics are the major game changers that comprise sizeable complex protein molecules such as monoclonal antibodies and receptor fusion proteins which are to be administered parenterally, targeting the various inflammatory mediators and components of the immune system in the pathogenesis of psoriasis. The selective IL-23 p19 inhibitors have demonstrated very high efficacy in clinical trials without any significant safety concerns holding a lot of promise. But how they perform in the real-clinical setting is a question that needs to be extensively analyzed. Presently many small molecules for oral and topical use are in various stages of development and clinical trials. JAK inhibitors and tyrosine kinase two inhibitors seem to be potentially promising due to their efficacy and favorable safety profiles. With multiple arrays of drugs available targeting numerous mediators, proteins, genes, enzymes, and receptors implicated in the pathogenesis of such a complex and multifactorial disease, the clinician's job to select the effective therapy for a patient is becoming more and more challenging. The other parameters like the unpredictability of a patient's response to a particular therapy, cost of biologics, and socio-economic burden of the disease are the limiting factors due to which there is poor patient compliance. Biosimilars based on established biologics can provide a cost-effective solution to psoriatic patients. Though systemic biologicals have revolutionized the antipsoriatic therapy, the urgent and unmet need for easy availability of cost-effective biosimilars, more effective topical therapies for treating mild to moderate psoriasis, early diagnosis and intervention, and use of OMICS data for identifying novel targets should be the guiding principles and major driving force for future research in the field of antipsoriatic therapy.

\section{CONFLICT OF INTEREST}

The authors declare that there are no conflicts of interest.

\section{AUTHOR CONTRIBUTION STATEMENT}

Literature search and preparation of the manuscript (Shaik S.), conceptualization, review and final drafting/editing of the review (Dhaneshwar S.).

\section{REFERENCES}

Affandi, A. M., Khan, I., Saaya, N. N. (2018). Epidemiology and clinical features of adult patients with psoriasis in malaysia: 10-year review from the malaysian psoriasis registry (20072016). Dermatology Research and Practice, doi:10.1155/2018/4371471

Allen, J. G., \& Bloxham, D. P. (1989). The pharmacology and pharmacokinetics of the retinoids. Pharmacology \& Therapeutics, 40, 1-27. doi:10.1016/0163-7258(89)90071-5

Asarch, A., Barak, O., Loo, D. S., Gottlieb, A. B. (2008). Th17 cells: a new therapeutic target in inflammatory dermatoses. The Journal of Dermatological Treatment, 19(6), 318-326. doi:10.1080/09546630802206660

Ashburn, T. T., \& Thor, K. B. (2004). Drug repositioning: Identifying and developing new uses for existing drugs. Nature Reviews Drug Discovery, 3, 673-683. doi:10.1038/nrd1468

Bertelsen, T., Ljungberg, C., Litman, T., Huppertz, C., Hennze, R., Rønholt, K., Iversen, L., Johansen, C. (2020). I $\kappa$ B $\zeta$ is a key player in the antipsoriatic effects of secukinumab. The Journal of Al- 
lergy and Clinical Immunology, 145(1), 379-390. doi:10.1016/j.jaci.2019.09.029

Bhushan, M., Young, H. S., Brenchley, P. E., Griffiths, C. E. (2002). Recent advances in cutaneous angiogenesis. The British Journal of Dermatology, 147, 418-425. doi:10.1046/j.1365-2133.2002.05003.x

Bigler, J., Rand, H. A., Kerkof, K., Timour, M., Russell, C. B. (2013). Cross-study homogeneity of psoriasis gene expression in skin across a large expression range. PloS One, 8, e52242. doi:10.1371/journal.pone. 0052242

Bos, J. D., Hagenaars, C., Das, P. K., Krieg, S. R., Voorn, W. J., Kapsenberg, M. L. (1989). Predominance of "memory" T cells (CD4+, CDw29+) over "naive" $\mathrm{T}$ cells (CD4+, CD45R+) in both normal and diseased human skin. Archives of Dermatological Research, 281, 24-30. doi:10.1007/BF00424268

Bos, J. D., Hulsebosch, H. J., Krieg, S. R., Bakker, P. M., Cormane, R. H. (1983). Immunocompetent cells in psoriasis. Archives of Dermatological Research, 275, 181-189. doi:10.1007/BF00510050

Brandrup, F., Holm, N., Grunnet, N., Henningsen, K., Hansen, H. E. (1982). Psoriasis in monozygotic twins: variations in expression in individuals with identical genetic constitution. Acta Dermato-Venereologica, 62, 229-236.

Breckenridge, A., \& Jacob, R. (2019). Overcoming the legal and regulatory barriers to drug repurposing. Nature Reviews Drug Discovery, 18, 1-2. doi:10.1038/nrd.2018.92

Brownell I, \& Strober BE. (2007). Folate with methotrexate: Big benefit, questionable cost. British Journal of Dermatology, 157, 213. doi:10.1111/ j.1365-2133.2007.08005.x

Cantatore, F.P., Maruotti, N., Corrado, A., Ribatti, D. (2017). Anti-angiogenic effects of biotechnological therapies in rheumatic diseases. Biologics: Targets and Therapy 7:11, 123-128. doi:10.2147/ BTT.S143674.
Camisa C. (2000). Psoriasis: A clinical update on diagnosis and new therapies. Cleveland Clinic Journal of Medicine, 67, 105-119. doi:10.3949/ ccjm.67.2.105

Chan, J., Smoller, B. R., Raychauduri, S. P., Jiang, W. Y., Farber, E. M. (1997). Intraepidermal nerve fiber expression of calcitonin gene-related peptide, vasoactive intestinal peptide and substance $\mathrm{P}$ in psoriasis. Archives of Dermatological Research, 289(11), 611-616. doi:10.1007/s004030050249

Chang, J. C., Smith, L. R., Froning, K. J., Schwabe, B. J., Laxer, J. A., Caralli, L. L., Kurland, H. H., Karasek, M. A., Wilkinson, D. I., Carlo, D. J. (1994). CD8+ $\mathrm{T}$ cells in psoriatic lesions preferentially use T-cell receptor V beta 3 and/or V beta 13.1 genes. Proceedings of the National Academy of Sciences of the United States of America, 91, 9282-9286. doi:10.1073/pnas.91.20.9282

Chang, S. E., Han, S. S., Jung, H. J., Choi, J. H. (2007). Neuropeptides and their receptors in psoriatic skin in relation to pruritus. The British Journal of Dermatology, 156(6), 1272-1277. doi:10.1111/ j.1365-2133.2007.07935.x

Christophers E. (2001). Psoriasis--epidemiology and clinical spectrum. Clinical and Experimental Dermatology, 26, 314-320. doi:10.1046/j.13652230.2001.00832.x

Christophers, E., Segaert, S., Milligan, G., Molta, C. T., Boggs, R. (2013). Clinical improvement and satisfaction with biologic therapy in patients with severe plaque psoriasis: results of a European cross-sectional observational study. The Journal of dermatological treatment, 24(3), 193-198. doi:10.3 109/09546634.2012.697112

Coimbra, S., Figueiredo, A., Castro, E., Rocha-Pereira, P., Santos-Silva, A. (2012). The roles of cells and cytokines in the pathogenesis of psoriasis. International Journal of Dermatology, 51, 389-398. doi:10.1111/j.1365-4632.2011.05154.x 
Colombo, M. D., Cassano, N., Bellia, G., Vena, G. A. (2013). Cyclosporine regimens in plaque psoriasis: An overview with special emphasis on dose, duration, and old and new treatment approaches. The Scientific World Journal, 1-11. doi:10.1155/2013/805705

Corporation, C., Yazici, Y., \& Associate, C. (2019). FDA approves OTEZLA ${ }^{\circledast}$ (apremilast) for the treatment of oral ulcers associated with Behçet'sdisease | Celgene Corporation. https://ir.celgene.com/ press-releases-archive/press-release-details/2019/ FDA-Approves-OTEZLA-apremilast-for-theTreatment-of-Oral-Ulcers-Associated-with-Behets-Disease/default.aspx. Access date: April 2021

Corsello, S. M., Bittker, J. A., Liu, Z., Gould, J., McCarren, P., Hirschman, J. E., Johnston, S. E., Vrcic, A., Wong, B., Khan, M., Asiedu, J., Narayan, R., Mader, C. C., Subramanian, A., Golub, T. R. (2017). The Drug Repurposing Hub: a next-generation drug library and information resource. Nature Medicine, 23, 405-408. doi:10.1038/nm.4306

David, M., Akerman, L., Ziv, M., Kadurina, M., Gospodinov, D., Pavlotsky, F., Yankova, R., Kouzeva, V., Ramon, M., Silverman, M. H., Fishman, P. (2012). Treatment of plaque-type psoriasis with oral CF101: Data from an exploratory randomized phase 2 clinical trial. Journal of the European Academy of Dermatology and Venereology, 26, 361-367. doi:10.1111/j.1468-3083.2011.04078.x

de Cid, R., Riveira-Munoz, E., Zeeuwen, P. L., Robarge, J., Liao, W., Dannhauser, E. N., Giardina, E., Stuart, P. E., Nair, R., Helms, C., Escaramís, G., Ballana, E., Martín-Ezquerra, G., den Heijer, M., Kamsteeg, M., Joosten, I., Eichler, E. E., Lázaro, C., Pujol, R. M., Armengol, L., Estivill, X. (2009). Deletion of the late cornified envelope LCE3B and LCE3C genes as a susceptibility factor for psoriasis. Nature Genetics, 41, 211-215. doi:10.1038/ ng.313
Ding, W., Stohl, L. L., Xu, L., Zhou, X. K., Manni, M., Wagner, J. A., Granstein, R. D. (2016). Calcitonin Gene-Related Peptide-Exposed Endothelial Cells Bias Antigen Presentation to CD4+ T Cells toward a Th17 Response. Journal of Immunology (Baltimore, Md. : 1950), 196(5), 2181-2194. doi:10.4049/jimmunol.1500303

Dogra, S., \& Kaur, I. (2010). Childhood psoriasis. Indian Journal of Dermatology, Venereology and Leprology, 76, 357-365. doi:10.4103/0378-6323.66580

Elder, J. T., Bruce, A. T., Gudjonsson, J. E., Johnston, A., Stuart, P. E., Tejasvi, T., Voorhees, J. J., Abecasis, G. R., Nair, R. P. (2010). Molecular dissection of psoriasis: integrating genetics and biology. The Journal of Investigative Dermatology, 130, 12131226. doi:10.1038/jid.2009.319

Ellis, C. N., Krueger, G. G., \& Alefacept Clinical Study Group (2001). Treatment of chronic plaque psoriasis by selective targeting of memory effector T lymphocytes. The New England Journal of Medicine, 345, 248-255. doi:10.1056/ NEJM200107263450403

Farber, E. M., Nall, M. L., Watson, W. (1974). Natural history of psoriasis in 61 twin pairs. Archives of Dermatology, 109, 207-211.

Farkas, A., Kemény, L., Szöny, B. J., Bata-Csörgö, Z., Pivarcsi, A., Kiss, M., Széll, M., Koreck, A., Dobozy, A. (2001). Dithranol upregulates IL-10 receptors on the cultured human keratinocyte cell line HaCaT. Inflammation Research, 50, 44-49. doi:10.1007/s000110050723

Fishman, P., \& Cohen, S. (2016). The A3 adenosine receptor (A3AR): therapeutic target and predictive biological marker in rheumatoid arthritis. Clinical Rheumatology, 35, 2359-2362. doi:10.1007/ s10067-016-3202-4 
Fishman, P., Bar-Yehuda, S., Liang, B. T., Jacobson, K. A. (2012). Pharmacological and therapeutic effects of A3 adenosine receptor agonists. Drug Discovery Today, 17, 359-366. doi:10.1016/j.drudis.2011.10.007

Foss F. M. (2000). DAB (389) IL-2 (denileukindiftitox, ONTAK): a new fusion protein technology. Clinical Lymphoma, 1, S27-S31.

Fridman, J. S., Scherle, P. A., Collins, R., Burn, T., Neilan, C. L., Hertel, D., Contel, N., Haley, P., Thomas, B., Shi, J., Collier, P., Rodgers, J. D., Shepard, S., Metcalf, B., Hollis, G., Newton, R. C., Yeleswaram, S., Friedman, S. M., Vaddi, K. (2011). Preclinical evaluation of local JAK1 and JAK2 inhibition in cutaneous inflammation. The Journal of Investigative Dermatology, 131, 1838-1844. doi:10.1038/ jid.2011.140

Fuchs, E., \& Raghavan, S. (2002). Getting under the skin of epidermal morphogenesis. Nature reviews. Genetics, 3, 199-209. doi:https://doi.org/10.1038/nrg758

Gene Ontology Consortium (2008). The Gene Ontology project in 2008. Nucleic Acids Research, 36, D440D444. doi:10.1093/nar/gkm883

Goffe, B., \& Cather, J. C. (2003). Etanercept: An overview. Journal of the American Academy of Dermatology, 49, S105-S111. doi:10.1016/mjd.2003.554

Gordon, K. B., Blauvelt, A., Papp, K. A., Langley, R. G., Luger, T., Ohtsuki, M., Reich, K., Amato, D., Ball, S. G., Braun, D. K., Cameron, G. S., Erickson, J., Konrad, R. J., Muram, T. M., Nickoloff, B. J., Osuntokun, O. O., Secrest, R. J., Zhao, F., Mallbris, L., Leonardi, C. L., ... UNCOVER-3 Study Group (2016). Phase 3 Trials of Ixekizum$\mathrm{ab}$ in Moderate-to-Severe Plaque Psoriasis. The New England Journal of Medicine, 375, 345-356. doi:10.1056/NEJMoa1512711
Gottlieb, S. L., Gilleaudeau, P., Johnson, R., Estes, L., Woodworth, T. G., Gottlieb, A. B., Krueger, J. G. (1995). Response of psoriasis to a lymphocyte-selective toxin (DAB389IL-2) suggests a primary immune, but not keratinocyte, pathogenic basis. Nature Medicine, 1, 442-447. doi:10.1038/ nm0595-442

Granstein RD. (2001). New treatments for psoriasis. New England Journal of Medicine, 345, 284-287. doi:10.1056/NEJM200107263450410

Greaves, M. W., \& Weinstein, G. D. (1995). Treatment of psoriasis. The New England Journal of Medicine, 332, 581-588. doi:10.1056/ NEJM199503023320907

Griffiths, C. E., \& Barker, J. N. (2007). Pathogenesis and clinical features of psoriasis. Lancet, 370, 263271. doi:10.1016/S0140-6736(07)61128-3

Guttman-Yassky, E., Vugmeyster, Y., Lowes, M. A., Chamian, F., Kikuchi, T., Kagen, M., Gilleaudeau, P., Lee, E., Hunte, B., Howell, K., Dummer, W., Bodary, S. C., Krueger, J. G. (2008). Blockade of CD11a by efalizumab in psoriasis patients induces a unique state of T-cell hyporesponsiveness. The Journal of Investigative Dermatology, 128(5), 1182-1191. doi:10.1038/jid.2008.4

Haegerstrand, A., Jonzon, B., Dalsgaard, C. J., Nilsson, J. (1989). Vasoactive intestinal polypeptide stimulates cell proliferation and adenylate cyclase activity of cultured human keratinocytes. Proceedings of the National Academy of Sciences of the United States of America, 86, 5993-5996. doi:10.1073/ pnas.86.15.5993

Halling-Brown, M. D., Bulusu, K. C., Patel, M., Tym, J. E., Al-Lazikani, B. (2012). canSAR: an integrated cancer public translational research and drug discovery resource. Nucleic Acids Research, 40, D947-D956. doi:10.1093/nar/gkr881 
Hamdoun, S., Jung, P., Efferth, T. (2017). Drug repurposing of the anthelmintic niclosamide to treat multidrug-resistant leukemia. Frontiers in Pharmacology, 8, 1-11. doi:10.3389/fphar.2017.00110

Harel, A., Inger, A., Stelzer, G., Strichman-Almashanu, L., Dalah, I., Safran, M., Lancet, D. (2009). GIFtS: annotation landscape analysis with GeneCards. BMC Bioinformatics, 10, 348. doi:10.1186/1471-2105-10-348

Hsu, L., \& Armstrong, A. W. (2014). JAK inhibitors: treatment efficacy and safety profile in patients with psoriasis. Journal of immunology research, 2014, 283617. doi:10.1155/2014/283617

Iannone, F., \& Lapadula, G. (2012). The inhibitor of costimulation of $\mathrm{T}$ cells: abatacept. The Journal of rheumatology. Supplement, 89, 100-102. doi:10.3899/jrheum.120257

Kimball, A. B., Gordon, K. B., Langley, R. G., Menter, A., Chartash, E. K., Valdes, J., ABT-874 Psoriasis Study Investigators (2008). Safety and efficacy of ABT-874, a fully human interleukin $12 / 23$ monoclonal antibody, in the treatment of moderate to severe chronic plaque psoriasis: results of a randomized, placebo-controlled, phase 2 trial. Archives of dermatology, 144(2), 200-207. doi:10.1001/archdermatol.2007.63

Kodji, X., Arkless, K. L., Kee, Z., Cleary, S. J., Aubdool, A. A., Evans, E., Caton, P., Pitchford, S. C., Brain, S. D. (2019). Sensory nerves mediate spontaneous behaviors in addition to inflammation in a murine model of psoriasis. FASEB Journal, 33, 1578-1594. doi:10.1096/f.201800395RR

Kragballe, K. (1995). Calcipotriol: A New DrugforTopical Psoriasis Treatment. Pharmacology \& Toxicology, 77, 241-246. doi:10.1111/j.1600-0773.1995. tb01020.x
Krueger J. G. (2002). The immunologic basis for the treatment of psoriasis with new biologic agents. Journal of the American Academy of Dermatology, 46, 1-26. doi:10.1067/mjd.2002.120568

Krueger, G., Koo, J., Lebwohl, M., Menter, A., Stern, R. S., Rolstad, T. (2001). The impact of psoriasis on quality of life: results of a 1998 National Psoriasis Foundation patient-membership survey. Archives of Dermatology, 137, 280-284.

Krueger, J. G., \& Bowcock, A. (2005). Psoriasis pathophysiology: current concepts of pathogenesis. Annals of the Rheumatic Diseases, 64, ii30-ii36. doi:10.1136/ard.2004.031120

Krueger, J. G., Fretzin, S., Suárez-Fariñas, M., Haslett, P. A., Phipps, K. M., Cameron, G. S., McColm, J., Katcherian, A., Cueto, I., White, T., Banerjee, S., Hoffman, R. W. (2012). IL-17A is essential for cell activation and inflammatory gene circuits in subjects with psoriasis. The Journal of Allergy and Clinical Immunology, 130, 145-154.doi:10.1016/j. jaci.2012.04.024

Krueger, J. G., Walters, I. B., Miyazawa, M., Gilleaudeau, P., Hakimi, J., Light, S., Sherr, A., Gottlieb, A. B. (2000). Successful in vivo blockade of CD25 (high-affinity interleukin 2 receptor) on $\mathrm{T}$ cells by administration of humanized anti-Tac antibody to patients with psoriasis. Journal of the American Academy of Dermatology, 43, 448-458. doi:10.1067/mjd.2000.106515

Kui, R., Gal, B., Gaal, M., Kiss, M., Kemeny, L., Gyulai, R. (2016) Presence of antidrug antibodies correlates inversely with the plasma tumor necrosis factor (TNF)-alpha level and the efficacy of TNF-inhibitor therapy in psoriasis. J Dermatol, 43, 1018-1023.doi:10.1111/1346-8138.13301 
Kuijpers, A. L., van Dooren-Greebe, J. V., van de Kerkhof, P. C. (1997). Failure of combination therapy with acitretin and cyclosporin $\mathrm{A}$ in 3 patients with erythrodermic psoriasis. Dermatology, 194, 88-90. doi:10.1159/000246070

Kulski, J. K., Kenworthy, W., Bellgard, M., Taplin, R., Okamoto, K., Oka, A., Mabuchi, T., Ozawa, A., Tamiya, G., Inoko, H. (2005). Gene expression profiling of Japanese psoriatic skin reveals an increased activity in molecular stress and immune response signals. Journal of Molecular Medicine, 83, 964-975. doi:10.1007/s00109-005-0721-x

Kupper, T. S. (2003). Immunologic targets in psoriasis. New England Journal of Medicine, 349, 19871990. doi:https://doi.org/10.1056/NEJMp038164

Langley, R.G.; Papp, K.; Bissonnette, R.; Toth, D.; Matheson, R.; Hultquist, M.; White B. (2010). Safety profile of intravenous and subcutaneous siplizumab, an anti-CD2 monoclonal antibody, for the treatment of plaque psoriasis: results of two randomized, double-blind, placebo-controlled studies. International Journal of Dermatology, 49,818828. doi: 10.1111/j.1365-4632.2010.04512.x

Lebwohl M. (1997). Topical application of calcipotriene and corticosteroids: combination regimens. Journal of the American Academy of Dermatology, 37, S55-S58.

Lebwohl, M. G., Bachelez, H., Barker, J., Girolomoni, G., Kavanaugh, A., Langley, R. G., Paul, C. F., Puig, L., Reich, K., van de Kerkhof, P. C. (2014). Patient perspectives in the management of psoriasis: results from the population-based Multinational Assessment of Psoriasis and Psoriatic Arthritis Survey. Journal of the American Academy of Dermatology, 70(5), 871-81.e830. doi:10.1016/j. jaad.2013.12.018
Lebwohl, M. G., Papp, K. A., Stein Gold, L., Gooderham, M. J., Kircik, L. H., Draelos, Z. D., Kempers, S. E., Zirwas, M., Smith, K., Osborne, D. W., Trotman, M. L., Navale, L., Merritt, C., Berk, D. R., Welgus, H. (2020). Trial of Roflumilast Cream for Chronic Plaque Psoriasis. The New England Journal of Medicine, 383, 229-239. doi:10.1056/NEJMoa2000073

Li, H., Zuo, J., Tang, W. (2018). Phosphodiesterase-4 Inhibitors for the Treatment of Inflammatory Diseases. Frontiers in Pharmacology, 9, 1048. doi:10.3389/fphar.2018.01048

LiverTox: Clinical and Research Information on Drug-Induced Liver Injury. (2012). National Institute of Diabetes and Digestive and Kidney Diseases.

Lowes, M. A., Bowcock, A. M., Krueger, J. G. (2007). Pathogenesis and therapy of psoriasis. Nature, 445, 866-873. doi:10.1038/nature05663

Lowes, M. A., Russell, C. B., Martin, D. A., Towne, J. E., Krueger, J. G. (2013). The IL-23/T17 pathogenic axis in psoriasis is amplified by keratinocyte responses. Trends in Immunology, 34, 174-181. doi:10.1016/j.it.2012.11.005

Lowes, M. A., Suárez-Fariñas, M., Krueger, J. G. (2014). Immunology of psoriasis. Annual Review of Immunology, 32, 227-255. doi:10.1146/annurev-immunol-032713-120225

Malhotra, R., Stenn, K. S., Fernandez, L. A., Braverman, I. M. (1989). Angiogenic properties of normal and psoriatic skin associate with epidermis, not dermis. Laboratory Investigation; A Journal of Technical Methods and Pathology, 61, 162-165.

Martin, G., Guérard, S., Fortin, M. M., Rusu, D., Soucy, J., Poubelle, P. E., Pouliot, R. (2012). Pathological crosstalk in vitro between $T$ lymphocytes and lesional keratinocytes in psoriasis: necessity of direct cell-to-cell contact. Laboratory Investigation; A Journal of Technical Methods and Pathology, 92, 1058-1070. doi:10.1038/labinvest.2012.69 
Mason, J., Mason, A. R., Cork, M. J. (2002). Topical preparations for the treatment of psoriasis: a systematic review. The British Journal of Dermatology, 146, 351-364. doi:10.1046/j.13652133.2000.04713.x

McInnes, I., Mease, P., Reich, K., Nash, P., Andersson, M., Abrams, K., Fox, T. (2018). Secukinum$\mathrm{ab}$ demonstrates consistent safety over longterm exposure in patients with psoriatic arthritis and moderate-to-severe plaque psoriasis: updated pooled safety analyses. Rheumatology, 57. 185 doi:10.1093/rheumatology/key075.409

Mease, P. J., Gladman, D. D., Keystone, E. C., Alefacept in Psoriatic Arthritis Study Group (2006). Alefacept in combination with methotrexate for the treatment of psoriatic arthritis: results of a randomized, double-blind, placebo-controlled study. Arthritis and Rheumatism, 54(5), 16381645. doi:10.1002/art.21870

Mehta, D., Granstein, R. D. (2019). Immunoregulatory Effects of Neuropeptides on Endothelial Cells: Relevance to Dermatological Disorders. Dermatology, 235, 175-186. doi:10.1159/000496538

Menter, A., Feldman, S. R., Weinstein, G.D., Papp, K., Evans, R., Guzzo, C, Li, S., Dooley, L. T., Arnold, C., Gottlieb, A. B. (2007) A randomized comparison of continuous vs. Intermittent infliximab maintenance regimens over 1 year in the treatment of moderate-to-severe plaque psoriasis J Am Acad Dermatol, 56, 31-44. doi:10.1016/j. jaad.2006.07.017

Mezentsev, A., Nikolaev, A., Bruski, S. (2014). Matrix metalloproteinases and their role in psoriasis. Gene, 540, 1-10. doi:10.1016/j.gene.2014.01.068

Miossec, P., Kolls, J. K. (2012). Targeting IL-17 and TH17 cells in chronic inflammation. Nature Reviews Drug Discovery, 11, 763-776. doi:10.1038/ $\operatorname{nrd} 3794$
Moustafa, F., \& Feldman, S. R. (2014). A review of phosphodiesterase-inhibition and the potential role for phosphodiesterase 4-inhibitors in clinical dermatology. Dermatology Online Journal, 20 22608.

Mrowietz, U., Zhu, K., Christophers, E. (2000). Treatment of severe psoriasis with anti-CD25 monoclonal antibodies. Archives of Dermatology, 136(5), 675-676. doi:10.1001/archderm.136.5.675

Mudigonda, P., Mudigonda, T., Feneran, A. N., Alamdari, H. S., Sandoval, L., \& Feldman, S. R. (2012) Interleukin-23 and interleukin-17: importance in pathogenesis and therapy of psoriasis. Dermatology Online Journal, 18,1.

Nair, R. P., Duffin, K. C., Helms, C., Ding, J., Stuart, P. E., Goldgar, D., Gudjonsson, J. E., Li, Y., Tejasvi, T., Feng, B. J., Ruether, A., Schreiber, S., Weichenthal, M., Gladman, D., Rahman, P., Schrodi, S. J., Prahalad, S., Guthery, S. L., Fischer, J., Liao, W., ... Collaborative Association Study of Psoriasis (2009). Genome-wide scan reveals association of psoriasis with IL-23 and NF-kappaB pathways. Nature Genetics, 41, 199-204. doi:10.1038/ng.311

Nakamura, M., Toyoda, M., Morohashi, M. (2003). Pruritogenic mediators in psoriasis vulgaris: comparative evaluation of itch-associated cutaneous factors. The British Journal of Dermatology, 149(4), 718-730. doi:10.1046/j.1365-2133.2003.05586.x

Nashan, B., Moore, R., Amlot, P., Schmidt, A. G., Abeywickrama, K., Soulillou, J. P. (1997). Randomised trial of basiliximab versus placebo for control of acute cellular rejection in renal allograft recipients. CHIB 201 International Study Group. Lancet (London, England), 350(9086), 1193-1198. doi:10.1016/s0140-6736(97)09278-7 
Nijsten T, Margolis DJ, Feldman SR, Rolstad T, Stern RS. (2005).Traditional systemic treatments have not fully met the needs of psoriasis patients: results from a national survey. Journal of the American Academy of Dermatology, 52, 434-444. doi:10.1016/j.jaad.2004.10.862

Ortonne, J. P. (2003). Clinical response to alefacept: Results of a phase 3 study of intramuscular administration of alefacept in patient with chronic plaque psoriasis. Journal of the European Academy of Dermatology and Venereology, 17, 12-16. doi:10.1046/j.1468-3083.17.s2.3.x

Owen, C. M., Harrison, P. V. (2000). Successful treatment of severe psoriasis with basiliximab, an interleukin-2 receptor monoclonal antibody. Clinical and Experimental Dermatology, 25(3), 195-197. doi:10.1046/j.1365-2230.2000.00612.x

Papp, K. A., Blauvelt, A., Bukhalo, M., Gooderham, M., Krueger, J. G., Lacour, J. P., Menter, A., Philipp, S., Sofen, H., Tyring, S., Berner, B. R., Visvanathan, S., Pamulapati, C., Bennett, N., Flack, M., Scholl, P., Padula, S. J. (2017). Risankizumab versus ustekinumab for moderate-to-severe plaque psoriasis. The New England Journal of Medicine, 376, 1551-1560. doi:10.1056/NEJMoa1607017

Papp, K. A., Griffiths, C. E., Gordon, K., Lebwohl, M., Szapary, P. O., Wasfi, Y., Chan, D., Hsu, M. C., Ho, V., Ghislain, P. D., Strober, B., Reich, K., PHOENIX 1 Investigators, PHOENIX 2 Investigators, ACCEPT Investigators (2013). Long-term safety of ustekinumab in patients with moderate-to-severe psoriasis: final results from 5 years of follow-up. The British Journal of Dermatology, 168, 844-854. doi:10.1111/bjd.12214

Papp, K. A., Krueger, J. G., Feldman, S. R., Langley, R. G., Thaci, D., Torii, H., Tyring, S., Wolk, R., Gardner, A., Mebus, C., Tan, H., Luo, Y., Gupta, P., Mallbris, L., Tatulych, S. (2016). Tofacitinib, an oral Janus kinase inhibitor, for the treatment of chronic plaque psoriasis: Long-term efficacy and safety results from 2 randomized phase-III studies and 1 open-label long-term extension study. Journal of the American Academy of Dermatology, 74, 841-850. doi:10.1016/j.jaad.2016.01.013

Papp, K. A., Menter, M. A., Raman, M., Disch, D., Schlichting, D. E., Gaich, C., Macias, W., Zhang, X., Janes, J. M. (2016). A randomized phase 2b trial of baricitinib, an oral Janus kinase (JAK) 1/ JAK2 inhibitor, in patients with moderate-to-severe psoriasis. The British Journal of Dermatology, 174, 1266-1276. doi:10.1111/bjd.14403

Papp, K., Thaçi, D., Reich, K., Riedl, E., Langley, R. G., Krueger, J. G., Gottlieb, A. B., Nakagawa, H., Bowman, E. P., Mehta, A., Li, Q., Zhou, Y., Shames, R. (2015). Tildrakizumab (MK-3222), an anti-interleukin-23p19 monoclonal antibody, improves psoriasis in a phase IIb randomized placebo-controlled trial. The British Journal of Dermatology, 173, 930-939. doi:10.1111/bjd.13932

Pincelli, C., Schafer, P. H., French, L. E., Augustin, M., Krueger, J. G. (2018). Mechanisms Underlying the Clinical Effects of Apremilast for Psoriasis. Journal of Drugs in Dermatology, 17, 835-840.

Qu, X. A., Rajpal, D. K. (2012). Applications of Connectivity Map in drug discovery and development. Drug Discovery Today, 17, 1289-1298. doi:10.1016/j.drudis.2012.07.017

Quaranta, M., Knapp, B., Garzorz, N., Mattii, M., Pullabhatla, V., Pennino, D., Andres, C., Traidl-Hoffmann, C., Cavani, A., Theis, F. J., Ring, J., Schmidt-Weber, C. B., Eyerich, S., Eyerich, K. (2014). Intraindividual genome expression analysis reveals a specific molecular signature of psoriasis and eczema. Science Translational Medicine, 6, 244ra90. doi:https://doi.org/10.1126/scitranslmed.3008946 
Rahman, M., Zaki Ahmad, M., Kazmi, I., Akhter, S., Beg, S., Gupta, G., Afzal, M., Saleem, S., Ahmad, I., Adil Shaharyar, M., Jalees Ahmed, F., Anwar, F. (2012). Insight into the biomarkers as the novel anti-psoriatic drug discovery tool: a contemporary viewpoint. Current Drug Discovery Technologies, 9, 48-62. doi:10.2174/157016312799304516

Reich, K., Armstrong, A. W., Foley, P., Song, M., Wasfi, Y., Randazzo, B., Li, S., Shen, Y. K., Gordon, K. B. (2017). Efficacy and safety of guselkumab, an anti-interleukin-23 monoclonal antibody, compared with adalimumab for the treatment of patients with moderate to severe psoriasis with randomized withdrawal and retreatment: Results from the phase III, double-blind, placebo- and active comparator-controlled VOYAGE 2 trial. Journal of the American Academy of Dermatology, 76(3), 418-431. doi:10.1016/j.jaad.2016.11.042

Reich, K., Ortonne, J. P., Gottlieb, A. B., Terpstra, I. J., Coteur, G., Tasset, C., Mease, P. (2012). Successful treatment of moderate to severe plaque psoriasis with the PEGylated Fab' certolizumab pegol: results of a phase II randomized, placebo-controlled trial with a re-treatment extension. The British Journal of Dermatology, 167, 180-190. doi:10.1111/j.1365-2133.2012.10941.x

Reich, K., Nestle, F. O., Papp, K., Ortonne, J.P., Evans, R., Guzzo, C., Li, S., Dooley, L.T., x Griffiths, C. E.M. (2005) Infliximab induction and maintenance therapy for moderate-to-severe psoriasis: A phase III, multicentre, double-blind trial. Lancet, 36, 1367-1374.doi:10.1016/S0140 6736(05)67566-6

Reid, C \& Griffiths, C. E.M. Psoriasis and Treatment: Past, Present and Future Aspects. (2020) Acta DermVenereol, 100: adv00032.doi: 10.2340/000155553386
Reischl, J., Schwenke, S., Beekman, J. M., Mrowietz, U., Stürzebecher, S., Heubach, J. F. (2007). Increased expression of Wnt5a in psoriatic plaques. The Journal of Investigative Dermatology, 127, 163169. doi:10.1038/sj.jid.5700488

Rich, S. J., \& Bello-Quintero, C. E. (2004). Advancements in the treatment of psoriasis: role of biologic agents. Journal of Managed Care Pharmacy, 10, 318-325. doi:10.18553/jmcp.2004.10.4.318

Richard, B.W. \& Christopher, E.M.G. (2009) Adalimumab for the Treatment of Psoriasis. Expert Review of Dermatology, 4, 15-21. doi:10.1586/17469872.4.1.15

Rieder, E., \& Tausk, F. (2012). Psoriasis, a model of dermatologic psychosomatic disease: psychiatric implications and treatments. International Journal of Dermatology, 51(1), 12-26. doi:10.1111/j.13654632.2011.05071.x

Rønholt, K., Iversen, L. Old and new biological therapies for psoriasis. (2017). Int J Mol Sci. 18, 1-23. doi:10.3390/ijms18112297

Safran, M., Dalah, I., Alexander, J., Rosen, N., Iny Stein, T., Shmoish, M., Nativ, N., Bahir, I., Doniger, T., Krug, H., Sirota-Madi, A., Olender, T., Golan, Y., Stelzer, G., Harel, A., Lancet, D. (2010). GeneCards Version 3: the human gene integrator. Database: The Journal of Biological Databases and Curation, 2010, baq020. doi:10.1093/database/baq020

Salesi, N., Bossone, G., Veltri, E., Di Cocco, B., Marolla, P., Pacetti, U., Larosa, G., Muni, R., Vecchione, A. (2005). Clinical experience with bevacizum$\mathrm{ab}$ in colorectal cancer. Anticancer Research, 25, $3619-3623$

Salim, A., Emerson, R. M., Dalziel, K. L. (2000). Successful treatment of severe generalized pustular psoriasis with basiliximab (interleukin-2 receptor blocker). The British Journal of Dermatology, 143(5), 1121-1122. doi:10.1046/j.13652133.2000.03878.x 
Salim, A., Tan, E., Ilchyshyn, A., Berth-Jones, J. (2006). Folic acid supplementation during treatment of psoriasis with methotrexate: a randomized, double-blind, placebo-controlled trial. The British Journal of Dermatology, 154, 1169-1174. doi:10.1111/j.1365-2133.2006.07289.x

Samarasekera, E., Sawyer, L., Parnham, J., Smith, C. H., Guideline Development Group (2012). Assessment and management of psoriasis: summary of NICE guidance. BMJ, 345, e6712. doi:10.1136/ bmj.e6712

Sauder, D. N., Dekoven, J., Champagne, P., Croteau, D., Dupont, E. (2002). Neovastat (AE-941), an inhibitor of angiogenesis: Randomized phase I/II clinical trial results in patients with plaque psoriasis. Journal of the American Academy of Dermatology, 47, 535-541. doi:10.1067/mjd.2002.124702

Scher, R. K., Stiller, M., Zhu, Y. I. (2001). Tazarotene $0.1 \%$ gel in the treatment of fingernail psoriasis: a double-blind, randomized, vehicle-controlled study. Cutis, 68, 355-358.

Schlager, J. G., Rosumeck, S., Werner, R. N., Jacobs, A., Schmitt, J., Schlager, C., Nast, A. (2016). Topical treatments for scalp psoriasis. The Cochrane Database of Systematic Reviews, 2, CD009687. doi:10.1002/14651858.CD009687.pub2

Schön, M., Behmenburg, C., Denzer, D., Schön, M. P. (2001). Pathogenic function of IL-1 beta in psoriasiform skin lesions of flaky skin (fsn/fsn) mice. Clinical and Experimental Immunology, 123, 505-510. doi:/10.1046/j.1365-2249.2001.01421.x

Schonthaler, H. B., Huggenberger, R., Wculek, S. K., Detmar, M, Wagner E. F.(2009) Systemic anti-VEGF treatment strongly reduces skin inflammation in a mouse model of psoriasis, PNAS ; doi:10.1073/pnas.0907550106.
Schopf, R. E., Aust, H., Knop, J. (2002). Treatment of psoriasis with the chimeric monoclonal antibody against tumor necrosis factor $\alpha$, infliximab. Journal of the American Academy of Dermatology, 46, 886-891. doi:10.1067/mjd.2002.120472

Schwartz, D. M., Kanno, Y., Villarino, A., Ward, M., Gadina, M., O’Shea, J. J. (2017). JAK inhibition as a therapeutic strategy for immune and inflammatory diseases. Nature Reviews. Drug Discovery, 16(12), 843-862. doi:10.1038/nrd.2017.201

Seville R. H. (1976). Relapse rate of psoriasis worsened by adding steroids to a dithranol regime. The British Journal of Dermatology, 95, 643-646. doi:10.1111/j.1365-2133.1976.tb07038.x

Shah, K. A., Date, A. A., Joshi, M. D., Patravale, V. B. (2007). Solid lipid nanoparticles (SLN) of tretinoin: potential in topical delivery. International Journal of Pharmaceutics, 345, 163-171. doi:10.1016/j.ijpharm.2007.05.061

Shaker, O. G., Khairallah, M., Rasheed, H. M., Abdel-Halim, M. R., Abuzeid, O. M., Tawdi, A. M. E. Hadidi, H. H. E., Ashmaui, A. (2013) Antiangiogenic effect of methotrexate and PUVA on psoriasis. Cell Biochemistry Biophysics, 67(2): 735-42. doi: 10.1007/s12013-013-9563-2.

Smith, C. H., Barker, J. N. (2006). Psoriasis and its management. BMJ, 333, 380-384. doi:10.1136/ bmj.333.7564.380

Smith C.H, Jabbar-Lopez, Z. K., You, Z. Z., Bale, T., Burden, A.D., Coates, L. C., Cruickshank, M., Hadoke, T., MacMahon E., Murphy, R., Nelson-Piercy, C., Owen, C. M., Parslew, R., Peleva, E., Pottinger, E., Samarasekera, E. J., Stoddart, J., Strudwicke, C., Venning, V. A., Warren,R. B., Exton, L.S., MohdMustapa, M. F. (2016). British Association of Dermatologists guidelines for biologic therapy for psoriasis. Br J Dermatol, 38, 42-49. doi: 10.1111/bjd.15665 
Spitaler, M., Cantrell, D. A. (2004). Protein kinase $\mathrm{C}$ and beyond. Nature Immunology, 5, 785-790. doi:10.1038/ni1097

Sterry, W., Barker, J., Boehncke, W. H., Bos, J. D., Chimenti, S., Christophers, E., De La Brassinne, M. Ferrandiz, C., Griffiths, C., Katsambas, A., Kragballe, K., Lynde, C., Menter, A., Ortonne, J. P., Papp, K., Prinz, J., Rzany, B., Ronnevig, J., Saurat, J. H., Stahle, M., Voorhees, J. (2004). Biological therapies in the systemic management of psoriasis: International Consensus Conference. The British Journal of Dermatology, 151, 3-17. doi:10.1111/ j.1365-2133.2004.06070.x

Stuart, R. W., \& Racke, M. K. (2002). Targeting T cell costimulation in autoimmune disease. Expert Opinion on Therapeutic Targets, 6, 275-289. doi:10.1517/14728222.6.3.275

Suárez-Fariñas, M., Li, K., Fuentes-Duculan, J., Hayden, K., Brodmerkel, C., Krueger, J. G. (2012). Expanding the psoriasis disease profile: interrogation of the skin and serum of patients with moderate-to-severe psoriasis. The Journal of Investigative Dermatology, 132, 2552-2564. doi:10.1038/ jid.2012.184

Swindell, W. R., Johnston, A., Carbajal, S., Han, G., Wohn, C., Lu, J., Xing, X., Nair, R. P., Voorhees, J. J., Elder, J. T., Wang, X. J., Sano, S., Prens, E. P., DiGiovanni, J., Pittelkow, M. R., Ward, N. L., Gudjonsson, J. E. (2011). Genome-wide expression profiling of five mouse models identifies similarities and differences with human psoriasis. PloS One, 6, e18266. doi:10.1371/journal.pone.0018266

Tyring, S., Gottlieb, A., Papp, K., Gordon, K., Leonardi, C., Wang,A., Lalla, D., Woolley, M., Jahreis, A., Zitnik, R., Cella, D., Krishnan, R. (2006). Etanercept and clinical outcomes, fatigue, and depression in psoriasis: Double-blind placebo-controlledrandomised phase III trial. Lancet, 367, 29-35. doi: 10.1016/S0140-6736(05)67763-X.
Taylor P. C. (2001). Anti-tumor necrosis factor therapies. Current Opinion in Rheumatology, 13, 164169. doi:10.1097/00002281-200105000-00003

Thami, G., \& Sarkar, R. (2002). Coal tar: past, present and future. Clinical and Experimental Dermatology, 27, 99-103. doi:10.1046/j.13652230.2002.00995.x

Thatikonda, S., Pooladanda, V., Godugu, C. (2020). Repurposing an old drug for new use: Niclosamide in psoriasis-like skin inflammation. Journal of Cellular Physiology, 235(6), 5270-5283. doi:10.1002/ jcp.29413

Urdaneta, M., Jethwa, H., Sultan, R., Abraham, S. (2017). A review on golimumab in the treatment of psoriatic arthritis. Immunotherapy, 9, 871-889. doi:10.2217/imt-2017-0063

van der Schoot, L. S., van den Reek, J. M. P. A., Groenewoud, J. M. M., Otero, M. E., Njoo, M. D., Ossenkoppele, P. M., Mommers, J. M., Koetsier, M. I. A., Berends, M. A. M., Arnold, W. P., Peters, B., Andriessen, M. P. M., Den Hengst, C. W., Kuijpers, A. L. A., de Jong, E. M. G. J. (2019). Female patients are less satisfied with biological treatment for psoriasis and experience more side-effects than male patients: results from the prospective BioCAPTURE registry. Journal of the European Academy of Dermatology and Venereology, 33, 1913-1920. doi:10.1111/jdv.15733

Vidal Yucha, S. E., Tamamoto, K. A., Kaplan, D. L. (2019). The importance of the neuro-immuno-cutaneous system on human skin equivalent design. Cell Proliferation, 52, e12677. doi:10.1111/ cpr.12677

Weinstein G. D. (1997). Tazarotene gel: efficacy and safety in plaque psoriasis. Journal of the American Academy of Dermatology, 37, S33-S38. 
Willems, M., Dubois,N.,Musumeci,L., Bours, V.,Robe,

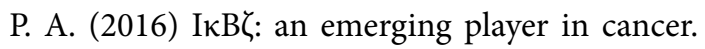
Oncotarget, 7(40), 66310-66322.doi: 10.18632/oncotarget.11624

Williams, R. E., Tillman, D. M., White, S. I., Barnett, E. L., Mackie, R. M. (1992). Re-examining crude coal tar treatment for psoriasis. The British Journal of Dermatology, 126, 608-610. doi:10.1111/j.1365-2133.1992.tb00108.x

Wilson, J. F. (2004). Angiogenesis therapy moves beyond cancer. Annals of Internal Medicine, 141, 165-168. doi:10.7326/0003-4819-141-2200407200-00027

Wingren, A. G., Parra, E., Varga, M., Kalland, T., Sjögren, H. O., Hedlund, G., Dohlsten, M. (1995). T cell activation pathways: B7, LFA-3, and ICAM1 shape unique $\mathrm{T}$ cell profiles. Critical Reviews in Immunology, 15, 235-253. doi:10.1615/critrevimmunol.v15.i3-4.30

Winterfield, L. S., \& Menter, A. (2004). Infliximab. Dermatologic Therapy, 17, 409-426. doi:10.1111/ j.1396-0296.2004.04044.x
Yadav, M., Rosenbaum, J., Goetzl, E. J.(2008). Cutting edge: vasoactive intestinal peptide (VIP) induces differentiation of Th17 cells with a distinctive cytokine profile. Journal of Immunology, 180, 27722776. doi:10.4049/jimmunol.180.5.2772

Yao, Y., Richman, L., Morehouse, C., de los Reyes, M., Higgs, B. W., Boutrin, A., White, B., Coyle, A., Krueger, J., Kiener, P. A., Jallal, B. (2008). Type I interferon: potential therapeutic target for psoriasis? PloS One, 3, e2737. doi:10.1371/journal. pone. 0002737

Zaba, L. C., Suárez-Fariñas, M., Fuentes-Duculan, J., Nograles, K. E., Guttman-Yassky, E., Cardinale, I., Lowes, M. A., Krueger, J. G. (2009). Effective treatment of psoriasis with etanercept is linked to suppression of IL-17 signaling, not immediate response TNF genes. The Journal of Allergy and Clinical Immunology, 124, 1022-10.e395. doi:10.1016/j.jaci.2009.08.046 